Acta Theriologica, Suppl. 5: 63-74, 1998.

PL ISSN 0001-7051

\title{
Allozyme variation in native red deer Cervus elaphus of Mesola Wood, northern Italy: implications for conservation
}

\author{
Rita LORENZINI, Stefano MATTIOLI and Rosario FICO
}

Lorenzini R., Mattioli S. and Fico R. 1998. Allozyme variation in native red deer Cervus elaphus of Mesola Wood, northern Italy: implications for conservation. [In: Ecological genetics in mammals III. G. B. Hartl and J. Markowski, eds]. Acta Theriologica, Suppl. 5: 63-74.

Screening of 43 protein loci was used to evaluate the level of genetic variability in 42 red deer Cervus elaphus Linnaeus, 1758 from Mesola Wood, the only native population presently occurring in peninsular Italy. The survey revealed polymorphism at four loci. In one of them evidence was provided for a significant deficiency of heterozygotes. Average expected heterozygosity and the proportion of polymorphic loci were $H_{e}=0.025$ and $P=0.093$, respectively. Although these values are low, they are consistent with those reported for other European red deer populations. Repeated bottlenecks and slow recoveries along with prolonged selective removal of stags were indicated as affecting genetic variation as a consequence of random drift. A genetic factor may have influenced female fertility and antler conformation. Comparisons with free-ranging deer from the Alps, and with an enclosed population yielded estimates of absolute (mean Nei's $1972 D=0.004, \mathrm{SD}=0.002$; mean modified Rogers' $D=0.063$, $\mathrm{SD}=0.013)$ and relative (Wright's $\left.F_{S T}=0.094\right)$ genetic distance typical for red deer populations. Given the biological value of Mesola red deer, genetic results are discussed in relation to both population history and conservation. A strategy for urgent management interventions is also proposed.

Istituto Zooprofilattico Sperimentale dell'Abruzzo e del Molise "G. Caporale", Campo Boario, 64100 Teramo, Italy (RL, RF); Dipartimento di Biologia Evolutiva, Università di Siena, Via Mattioli, 4, 53100 Siena, Italy (SM)

Key words: Cervus elaphus, protein electrophoresis, genetic variability, population history, conservation

\section{Introduction}

The "Gran Bosco della Mesola" Natural Reserve harbours the only native population of red deer Cervus elaphus Linnaeus, 1758 in the Italian peninsula (Castelli 1941, Mattioli 1990). All other extant populations originate either from natural recolonisation from neighbouring countries (central and eastern Alps) or from reintroductions (western Alps and Apennines). The sea and the malarial swamps that surrounded the Mesola Wood made it hardly accessible to man and saved the deer from extinction. In fact, this is one of the few European red deer populations that has managed to preserve its purity as it has never been subjected to traditional "blood-stock" improving procedures. This fact is particularly noteworthy, 
since red deer has suffered more than other game species from restocking operations for sporting purposes (Beninde 1940, Whitehead 1964, Mystkowska 1966, Lowe and Gardiner 1974, Geist 1989). On the other hand, Mesola red deer have sustained several human interferences. Isolated from all other populations for the past 3-7 centuries, this nucleus has always been confined to a restricted forest ( 2500 ha in 1800,1100 ha in 1900). It has been subjected to the effects of flooding, disease, hunting (until 1940), poaching, logging, competition of fallow deer and domestic animals, thus experiencing a number of demographic crashes and slow recoveries.

Mesola red deer has modest body size, a simple antler design, and a low reproductive success (Mattioli 1990, 1993a, b). Environmental restraints are obvious: scarce food resources supplied by an unproductive habitat have selected "maintenance phenotypes" (sensu Geist 1987), characterized by reduced stature, limited sexual dimorphism, and low recruitment. Contingent factors such as present heavy food competition by fallow deer, with consequent habitat deterioration, have further exacerbated the effects. The influence of genetic factors on the performance of this population is more controversial. Recently, a genetic component has been suggested for both the low female fertility and the antler conformation (Mattioli 1993a, b). The trophy-oriented shooting practiced throughout the years has eliminated the best stags, probably contributing to the development of an oversimplified antler structure (with bez tine and crown constantly absent over the past 40 years).

The purposes of the present study are: (1) to describe genetic polymorphism within the Mesola population; (2) to estimate the extent of genetic differentiation between Mesola and other Italian populations of red deer; (3) to evaluate the role of population history (autochthonous origin, multi-century isolation, population dynamics, selective removal) on the genetic characteristics of Mesola red deer, and (4) to develop a strategy for conservation and management.

\section{Material and methods}

\section{Study area}

Mesola Wood is located in the Po delta area, north-eastern Italy. It covers an area of 1058 ha, of which 850 ha are accessible to deer. The Elciola enclosure (97 ha) occupies the center of the Reserve. Forest habitats account for $87 \%$ of the territory, with Quercus ilex as the dominant tree species. This sub-mediterranean coastal wood originated on sandy dunes in late Middle Ages during a warm climate period. Managed for centuries as a coppice, it is now slowly being converted into a high forest. Besides red deer, Mesola Wood shelters an introduced population of fallow deer, the size of which varied from 350 to 1000 individuals over the past 15 years (with an estimated biomass of $16-45$ tons).

\section{Demography}

Seasonal surveys from 1982 onward have permitted a continuous monitoring of the population dynamics and of the reproductive performance of Mesola red deer, giving virtually exact numbers for the Elciola subpopulation, and reliable estimates for the other one. Population size figures concerning 
the period previous to 1982 are taken from Castelli (1941), Perco (1984), and Mattioli (1990). The male segment of the effective population size $\left(N_{e}\right)$ was assessed assuming that the actual breeders were only high rank adult stags (observed harem holders, 7-8 pointers, large-sized mature individuals). Opportunistic matings were excluded. The female segment was calculated considering hinds sighted with a calf at foot in summer. The yearly changes in population size are expressed as annual finite rate of increase $\lambda=e^{r}$ (Caughley 1977).

\section{Genetic analysis}

A total of 109 red deer from four sampling sites (Fig. 1) were analysed for electrophoretic variation. Samples of blood and skeletal muscle were collected by jugular puncture and biopsies, respectively, during 1994 through 1996 from 42 live red deer of Mesola Wood. Animals were captured by use of a dart gun and immobilizing drugs. Whole blood, serum or tissues (liver, heart) were obtained from caught or dead animals from Tarvisio $(n=32)$ and Stelvio $(n=13)$, eastern and central Alps, respectively. A fourth sample comprised red deer from an enclosure near Lucca $(n=22)$, central Italy. The latter is a mixed population, founded by individuals from different parts of the Alps, and by animals of unknown origin coming from zoos and private parks.

Blood cells and plasma were separated by centrifugation at $3000 \mathrm{rpm}$. Some aliquots of plasma were diluted 1:10 with distilled water before storing at $-80^{\circ} \mathrm{C}$. Red blood cells were frozen and thawed twice, then an equal volume of deionized water was added. About $0.5 \mathrm{~g}$ of heart, liver and muscle were

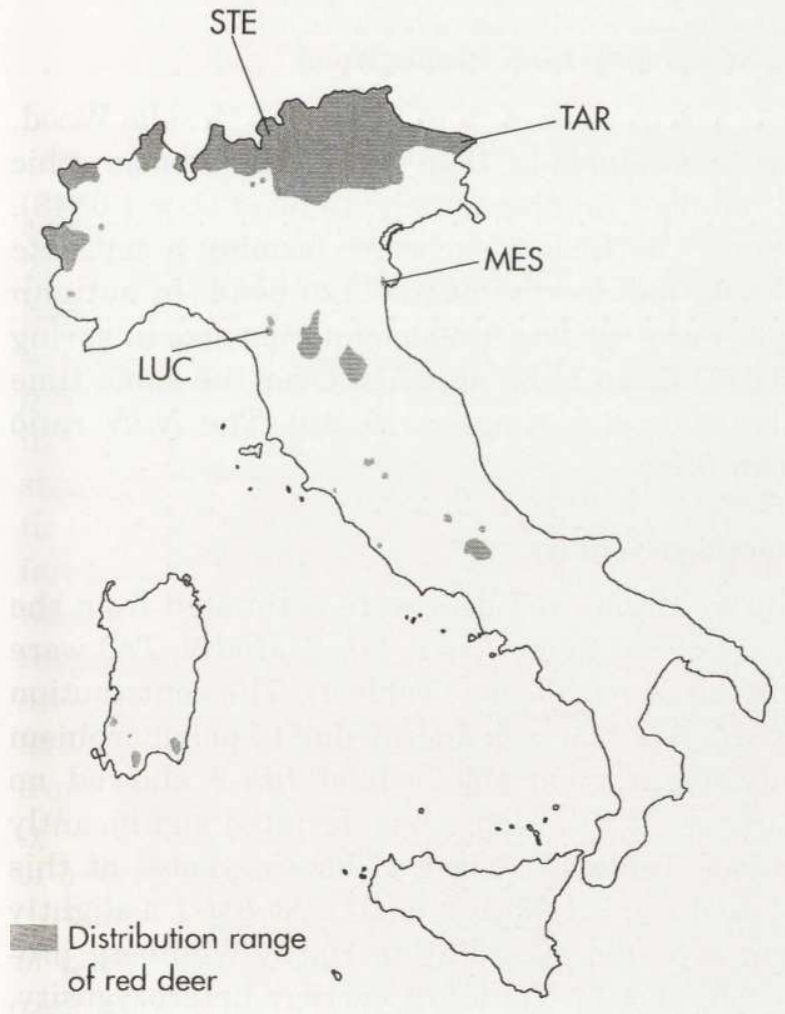

Fig. 1. Sampling sites of red deer in Italy. MES Mesola, STE - Stelvio, TAR - Tarvisio, LUC - Lucca. homogenized in $1 \mathrm{ml}$ of $0.01 \mathrm{M}$ Tris $/ \mathrm{HCl}$ pH 7.5, 0.001 M Na2EDTA, 0.001 ß-mercaptoethanol buffer, and centrifuged at $15000 \mathrm{rpm}$ at $+4^{\circ} \mathrm{C}$. Supernatants were diluted in an equal volume of $40 \%$ glycerol solution, and stored at $-80^{\circ} \mathrm{C}$ until analysis. Electrophoresis was performed at $+4^{\circ} \mathrm{C}$ on vertical and horizontal polyacrylamide gels using different electrophoretic conditions (Lorenzini et al. 1993) and staining recipes (Harris and Hopkinson 1976, Murphy et al. 1990). Hemoglobin was separated by isoelectric focusing in $0.5 \mathrm{~mm}$ acrylamide gels, using a pH 5.5-8.5 gradient (Pharmacia). General proteins were stained with Comassie Brilliant Blue R-250. The following 43 putative gene loci were consistently resolved in at least one population (E.C. numbers and tissues are given in parentheses: $\mathrm{H}$ - heart, $\mathrm{L}$ - liver, $\mathrm{M}$ muscle, Rbc - red blood cells, P/S plasma or serum): Aat-1, -2 (2.6.1.1, H, M), Acp-1, -2 (3.1.3.2, Rbc), Ada-1, -2 (3.5.4.4, H, M), Alb (P/S), Aldo (4.1.2.13, $\mathrm{H}, \mathrm{M}), A k-1,-2$ (2.7.4.3, H, M), Ca-1 (4.2.1.1, H, M), $\mathrm{Ca}-2$ (4.2.1.1., Rbc), Ck-1, -2 (2.7.3.2, H, M), Dia-1, -2 (1.6.2.2, Rbc), Est-1, -2 (3.1.1.1, P/S), Est-D (3.1.1.1, Rbc), Fh (4.2.1.2, H, M), General protein-1, -2 (H), Gpi (5.3.1.9, H, M), Hb-1, -2 (Rbc), Hk (2.7.1.1, H, 
M), Idh-1, -2 (1.1.1.42, H, M), Ldh-1, -2 (1.1.1.27, H, M), Mod-1, -2 (1.1.1.40, H, M), Mor-1, -2 (1.1.1.37, H, M), Mpi (5.3.1.8, Rbc, H, M), Pep-A, -B (3.4.11, H, M), Pgd (1.1.1.44, Rbc, L), Pgm (2.7.5.1, H, M), Sod-1, -2 (1.15.1.1, Rbc), Trf (P/S), Xdh (1.3.2.1, H, M).

Banding patterns of isozyme systems were compared on the same gel with those of red deer from central Europe analysed by Hartl et al. (1990). Allele frequencies were derived from allozyme genotypes on the gels. Populations were tested for deviation of genotype frequencies from Hardy-Weinberg expectations by a $\chi^{2}$-test (Sokal and Rohlf 1994) with Levene (1949) correction for small sample size $(n<30)$. Observed $\left(H_{o}\right)$ and expected $\left(H_{e}\right)$ average heterozygosity, and the proportion of polymorphic loci $(P, 99 \%$ criterion) were calculated for each population. The significance of differences among allelic frequencies in the four populations was determined through contingency table analyses and the $\chi^{2}$ statistics. Heterogeneity among populations at each variable locus was further estimated from the $F_{S T}$ index (Nei 1977, Wright 1978), and checked for statistical significance according to Workman and Niswander (1970). Values of Nei's standard (1972) and modified Rogers' (Wright 1978) genetic distance were calculated. Unweighted pair group arithmetic average (UPGMA) method (Sneath and Sokal 1973), Wagner (Farris 1972), and Fitch-Margoliash (1967) procedures were used to construct rooted and unrooted trees on the basis of matrices of genetic distances. Computations were performed using the programs BIOSYS-1, Release 1.7 (Swofford and Selander 1989), and PHYLIP (Felsenstein 1989).

\section{Results}

\section{Population history of red deer from Mesola Wood}

In the 1930's 250-300 red deer were estimated to roam in Mesola Wood. Population size dropped to about 10 individuals in 1945-1947. The demographic recovery was so slow that in 1970 red deer numbered only 40 head $(\lambda=1.0548)$. In 1972, 12 animals managed to enter the Elciola enclosure forming a separate subpopulation. In autumn 1980 Mesola red deer numbered 120 head. In autumn 1982 they dropped to $90(\lambda=0.9086)$. From 1982 to 1998 population size in spring decreased annually by $2.6 \%(\lambda=0.974)$ down to 59 animals. Over the same time span $N_{e}$ averaged 15.2 individuals $(\mathrm{SD}=2.9$, range $=10-20)$. The $N_{e} / N$ ratio ranged between 0.17 and 0.26 (mean 0.26 ).

\section{Genetic variability}

Parameters of genetic variability in Mesola red deer were estimated from the analysis of 43 presumptive gene loci. Four of them (Est-1, Idh-2, Mod-2, Trf) were polymorphic, with two alleles occurring at each locus (Table 1). The contribution to average observed heterozygosity $\left(H_{O}=0.023\right)$ was mainly due to polymorphism at Mod-2 and Est-1. Trf was only slightly variable, whilst $I d h-2$ showed no heterozygotes and genotypic proportions at this locus thus deviated significantly from Hardy-Weinberg proportions (see Table 1). A lack of heterozygotes at this locus was also indicated by the value of $F_{I S}=1.00(p<0.001)$. At Est-1 a slightly larger number of homozygotes than expected according to Hardy-Weinberg proportions was found $\left(p<0.08, \chi^{2}=3.0, \mathrm{df}=1\right)$. Values of average heterozygosity, the proportion of polymorphic loci, and the mean number of alleles per locus are also given in Table 1. 
Table 1. Allele frequencies, observed (expected) single locus heterozygosities $(h)$ at four polymorphic loci, and indices of genetic variability (calculated over 43 loci) in 42 red deer from Mesola Wood. $H_{o}\left(H_{e}\right)$ - observed (expected) average heterozygosity, $P$ - proportion of polymorphic loci, $n$ - mean number of alleles per locus. ns - not significant, ${ }^{*} *-p<$ $0.001{ }^{a}$ - all values with $1 \mathrm{df}$.

\begin{tabular}{lcccc}
\hline Locus & Allele & Frequency & \multicolumn{1}{c}{$h$} & Chi-square $^{\mathrm{a}}$ \\
\hline Mod-2 & $a$ & 0.682 & $0.545(0.434)$ & $1.5 \mathrm{~ns}$ \\
& $b$ & 0.318 & & 22.0 ** \\
Idh-2 & $a$ & 0.955 & $0.000(0.087)$ & $3.0 \mathrm{~ns}$ \\
& $b$ & 0.045 & & $0.2 \mathrm{~ns}$ \\
Est-1 & $a$ & 0.308 & $0.308(0.426)$ & \\
& $b$ & 0.692 & & \\
Trf & $a$ & 0.936 & $0.128(0.120)$ & \\
$H_{o}\left(H_{e}\right)$ & $b$ & 0.064 & & \\
$P$ & & & $0.023(0.025)$ & \\
$n$ & & & 1.1 & \\
\hline
\end{tabular}

\section{Genetic structure and differentiation of populations}

Because of the availability of serum or whole blood, but not of tissues for many samples, only 19 protein loci could be consistently scored in all populations (Table 2). Polymorphism was detected at four loci (Est-1, Trf, $\mathrm{Mpi}, \mathrm{Ca}-2)$ in at least one population. Sod-2 was variable in Stelvio (expected single locus heterozygosity, $h_{e}$ $=0.335, p>0.01$ for Hardy-Weinberg equilibrium) and Tarvisio $\left(h_{e}=0.069\right.$, $p>0.001$ ), and monomorphic in Mesola. However, being not consistently scorable in Lucca, this locus was not inclued in the computations. Allele frequencies differed significantly between populations, and $F_{S T}$ values at single loci ranged from 0.055 to 0.150 , with $p<0.01$ for all loci. Mean $F_{S T}$ revealed significant genetic differentiation also across loci among populations $\left(F_{S T}=0.094, p<0.001\right)$. This value, which was mainly due to differences at $\operatorname{Trf}$ and $\mathrm{Ca}-2\left(F_{S T}=0.130\right.$ and 0.150 , respectively), indicates that at least $9 \%$ of the total variability is attributable to divergence between populations. Private alleles (sensu Slatkin 1985) were found at $\mathrm{Mpi}$ in Stelvio and at $\mathrm{Ca}-2$ in Lucca, with relatively low frequencies. Departure from equilibrium was revealed at the Est-1 locus in the population of Stelvio $\left(\chi^{2}=7.0, \mathrm{df}=1, p<0.01\right)$, and at $C a-2$ in Lucca $\left(\chi^{2}=3.7, \mathrm{df}=1, p<0.05\right)$. Estimates of overall genetic variability in all populations are given in Table 2.

Comparisons between samples from Mesola and the other red deer, regardless of population subdivision (computations could be made on the basis of 37 loci), yielded estimates of observed (expected) heterozygosity of $0.012(0.017)$ and 0.033 (0.035), respectively, for Mesola and the pooled populations. $P$ was 0.081 in Mesola versus 0.189 in the combined sample. A mean $F_{S T}$ of 0.090 (significantly different 
Table 2. Allele frequencies at four polymorphic loci, and parameters of genetic variability (calculated over 19 loci, Sod-2 excluded) in four red deer populations from Italy. $H_{o}\left(H_{e}\right)$ - observed (expected) average heterozygosity, $P$ - proportion of polymorphic loci, $F_{S T}$ - fixation index (Wright 1978), * $-p$ $<0.01$, *** $-p<0.001$. ${ }^{a}$ - monomorphic loci: Sod-1, Hb-1, -2, Acp-1, -2, Alb, General protein-1, -2, Pgm, Pgi, Est-2, Est-D, Pgd, Dia-1,-2.

\begin{tabular}{|c|c|c|c|c|c|c|}
\hline \multirow[b]{2}{*}{ Locus $^{a}$} & \multirow[b]{2}{*}{ Allele } & \multicolumn{4}{|c|}{ Populations } & \multirow[b]{2}{*}{$F_{S T}$} \\
\hline & & $\begin{array}{c}\text { Mesola } \\
(n=42)\end{array}$ & $\begin{array}{l}\text { Stelvio } \\
(n=13)\end{array}$ & $\begin{array}{l}\text { Tarvisio } \\
(n=32)\end{array}$ & $\begin{array}{c}\text { Lucca } \\
(n=22)\end{array}$ & \\
\hline \multirow[t]{2}{*}{ Est-1 } & $a$ & 0.308 & 0.125 & 0.065 & 0.237 & $0.059^{*}$ \\
\hline & $b$ & 0.692 & 0.875 & 0.935 & 0.763 & \\
\hline \multirow[t]{2}{*}{$\operatorname{Trf}$} & $a$ & 0.936 & 0.708 & 0.935 & 1.0 & $0.130^{\text {*** }}$ \\
\hline & $b$ & 0.064 & 0.292 & 0.065 & 0.0 & \\
\hline \multirow[t]{2}{*}{ Mpi } & $a$ & 0.0 & 0.071 & 0.0 & 0.0 & $0.055^{*}$ \\
\hline & $b$ & 1.0 & 0.929 & 1.0 & 1.0 & \\
\hline \multirow[t]{2}{*}{$\mathrm{Ca}-2$} & $a$ & 1.0 & 1.0 & 1.0 & 0.810 & $0.150^{\text {*** }}$ \\
\hline & $b$ & 0.0 & 0.0 & 0.0 & 0.190 & \\
\hline \multirow[t]{2}{*}{ Sod-2 } & $a$ & 0.0 & 0.214 & 0.036 & not scored & - \\
\hline & $b$ & 1.0 & 0.786 & 0.964 & & \\
\hline$H_{o}$ & & 0.023 & 0.034 & 0.014 & 0.024 & \\
\hline$H_{e}$ & & 0.029 & 0.042 & 0.013 & 0.036 & \\
\hline$P$ & & 0.105 & 0.158 & 0.105 & 0.105 & \\
\hline
\end{tabular}

from zero at $p<0.001$ ) was quite the same as the value obtained when the four populations were considered separately $\left(F_{S T}=0.094\right)$. The same holds for genetic distances, which showed quite similar values when calculated considering either two (Nei's $D=0.005$, modified Rogers' $D=0.072$ ) or four populations (mean Nei's $D=0.004, \mathrm{SD}=0.002$, mean modified Rogers' $D=0.063, \mathrm{SD}=0.013$; Table 3). A Wagner tree obtained by rooting at midpoint of the longest path is displayed in Fig. 2. UPGMA and Fitch-Margoliash dendrograms based on Nei's and modified Rogers' distances (not shown) revealed the same topology as the Wagner network in Fig. 2.

Table 3. Nei's (1972) standard genetic distance, below diagonal, and modified Rogers' (Wright 1978) distance, above diagonal, between four Italian red deer populations.

\begin{tabular}{lcccc}
\hline & 1. Mesola & 2. Stelvio & 3. Tarvisio & 4. Lucca \\
\hline 1. & - & 0.069 & 0.056 & 0.049 \\
2. & 0.005 & - & 0.056 & 0.086 \\
3. & 0.003 & 0.003 & - & 0.061 \\
4. & 0.002 & 0.008 & 0.004 & -
\end{tabular}




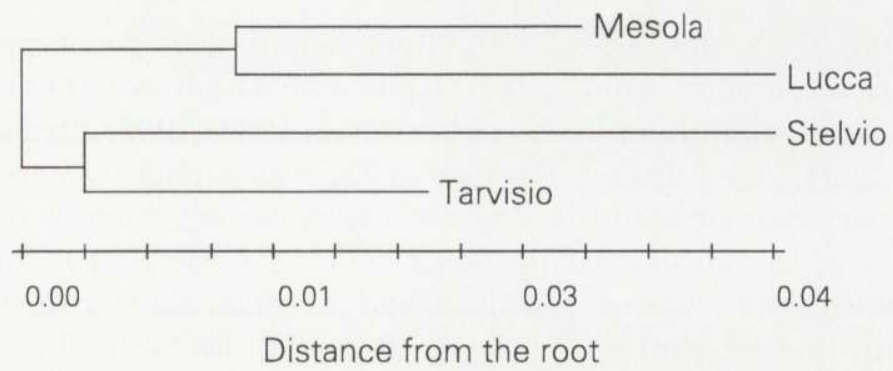

Fig. 2. Wagner tree (rooted at midpoint) based on the matrix of modified Rogers' genetic distances, displaying genetic relationships between the four red deer populations studied. Cophenetic correlation coefficient $=0.980$.

\section{Discussion}

The level of genetic variability in red deer from Mesola Wood is among the lowest as yet found in Cervus elaphus populations analysed for allozyme variation in Europe (Baccus et al. 1983, Dratch 1983, Dratch and Gyllensten 1983, Gyllensten et al. 1983, Hartl et al. 1990, 1993, Ströhlein et al. 1993, 1994). Of four polymorphic loci, Est-1 and Mod-2 contributed most to average heterozygosity. In contrast, $\operatorname{Trf}$ and $I d h-2$ proved to be only slightly polymorphic, although they were reported as highly variable in almost all the populations studied so far (Gyllensten 1980, Gyllensten et al. 1983, Pemberton et al. 1988, Hartl et al. 1990, 1993, Herzog et al. 1991, Stratil et al. 1990, Strandgaard and Simonsen 1993, Gehle and Herzog 1994, Schreiber et al. 1994). The low heterozygosity observed in this population for regularly highly polymorphic loci in red deer and the lack of rare alleles suggest that genetic isolation, along with repeated bottleneck events during the last centuries, have influenced both the mean level of genetic variability and the allelic diversity (see Soulé and Wilcox 1980, Frankel and Soulé 1987, Soulé 1987, for reviews).

In red deer the presence of certain alleles at the loci $I d h-2$ and $\operatorname{Trf}$ turned out to be significantly associated with some morphological characters and fitness components. Individuals homozygous for the allele $I d h-2^{b}$ showed a higher number of antler tines in males, and a larger hind foot length in females (Hartl et al. 1991, 1995a). Heterozygotes for $I d h-2^{a b}$ were associated with a better survival of calves, in particular of female ones (Pemberton et al. 1988). It was suggested that some form of selection (acting on the enzyme locus itself or on genes closely linked to it) might be responsible for the maintenance of polymorphism at this locus even in small-sized populations (Pemberton et al. 1988, Hartl et al. 1991, 1995a, b). Both the poor quality of antlers and the low reproductive performance of the Mesola population may be related to the very low frequency of the $b$ allele at Idh-2 (as representative of loci associated with phenotypic traits). The same association with juvenile survival as that for $I d h-2$ holds for the locus $\operatorname{Tr} f: \operatorname{Tr} f^{a b}$ calves were 
found to survive better than those with either homozygous genotypes (Pemberton et al. 1988). Trf occurred as a multiallelic locus with a high extent of heterozygosity in many red deer populations (Gyllensten et al. 1980, 1983, Stratil et al. 1990, Herzog et al. 1991). By contrast, in Mesola $\operatorname{Trf}$ was a slightly variable bi-alelic locus. If polymorphism at both $I d h-2$ and $\operatorname{Trf}$ is under selection in red deer, it can be argued that in the Mesola population random genetic drift has countervailed any possible selective advantage of alleles, and is responsible for the trend towards fixation. Extensive variation in red deer was found also at the loci Mod-2 (Fartl et al. 1991) and Est-1 (Pemberton et al. 1988), but no associations with phenotypic traits could be found or tested. In Mesola red deer, frequencies of variant aleles are quite high as those found in populations from Rhum, UK (Est-1: Pemberton et al. 1988), from Austria, France, and Hungary (Mod-2: Hartl et al. 1990). These results suggest that the morphological and fitness traits described for Mesolc red deer are influenced also by a genetic component which, in turn, is influenced by genetic drift resulting from bottlenecks, slow recovery rates, and variation in population size and composition. In particular, a founder effect might be invdved in the simple antler architecture (Mattioli 1993b), as suggested for other deer populations (McCullough 1982, Feldhamer et al. 1985, Kaji et al. 1988). Consitent changes in the genetic structure of populations due to long-lasting hunting are also well documented (Ryman et al. 1981, Scribner et al. 1985, Hartl et al. 1995a).

Taking into account some possible bias due to the reduced set of loci scored in all samples, the mean level of genetic variability in the Mesola population is quite similar to that of red deer from both the Alps and Lucca. Among the four populations examined the one from Stelvio showed the highest level of geretic variation, as could be expected from its demographic history. This population had established by natural dispersal of animals from the Swiss Alps. Isolation was prevented by high rates of gene flow, overcoming the genetic consequencts of founder effect and random drift. The lowest value of heterozygosity was fourd in the population of Tarvisio, which probably suffered from a founder effect folloving reintroduction in the adjacent Austrian Alps. For red deer from Lucca, which ived in an enclosure, a low heterozygosity and a decrease of allelic diversity was detected. On the other hand, a polymorphism at $\mathrm{Ca}-2$, never found in prerious studies on red deer, suggests the presence of foreign alleles in the founder s.ock. The somewhat closer relationship between the Lucca and the Mesola populaions displayed by the Wagner tree (see also Table 3) is rather due to a common ffect of drift than to a true genetic resemblance.

The values of heterozygosity obtained so far for red deer from both Italy (Misola included) and the rest of Europe are relatively low compared to other deer species (see Hartl et al. 1990, Dratch and Pemberton 1992, Ströhlein et al. 1994 for reviews). Taking into account that red deer is one of the most intensively manged game species in Europe, this is likely to be explained by habitat fragmentation, hunting, and reintroductions, which confined red deer in small and isoated populations, often affected by erosion of genetic variability. 
Relative genetic differentiation and absolute genetic distances obtained in this study were small between populations, suggesting that red deer from Mesola Wood clearly belong to the subspecies $C$. e. elaphus. Distances are consistent with the values found for other free-ranging and enclosed populations of red deer in Europe (Gyllensten et al. 1983, Hartl et al. 1990, 1991). However, in red deer the subspecies status, as suggested by morphological criteria (Groves and Grubb 1987), is difficult to define by biochemical (Strandgaard and Simonsen 1993) and molecular (Hartl et al. 1995b) methods. Apart from the subspecies status, the importance of preserving locally adapted populations, like Mesola red deer, is becoming more commonly accepted. Conservation measures should be adopted urgently to favour the growth of this Italian native population, thus minimizing the risk of further loss of genetic diversity and preventing the population from ultimate extinction (Gilpin and Soulé 1986). An increase of inbreeding across generations due to a low effective population size $\left(N_{e}\right)$ is estimated by $F=1 / 2 N_{e}$, where $F$ is defined as the rate of inbreeding per generation. In our case with mean $N_{e}=15.2$, we obtain $F=0.033$. This value is about three times the threshold of $1 \%$ at which natural selection can offset the tendency to the fixation of deleterious genes (Franklin 1980, Soulé 1980). Wright's (1969) basic formula defines the rate of loss of genetic variation in an ideal population as $H_{t}=H_{o}[1-F]^{t}$, where $H_{o}$ is the initial heterozygosity and $t$ is time in terms of generations. Considering $H_{O}=$ 0.023 in the Mesola population, then $H$ for $t=1$ is 0.022 , suggesting that $4.3 \%$ heterozygosity $(\Delta H=0.001)$ are lost per generation. If we assume that one generation lasts 8 years, less than $70 \%$ of the genetic variation still remains after 10 generations, a time span corresponding to 80 years. Owing to the influence of unpredictable factors on $N_{e}$ across years (ie variance in offspring production or in male reproductive success), the loss of heterozygosity as a function of $N_{e}$ could be even greater than predicted by the inbreeding formulas (Fitzsimmons et al. 1995).

In order to allow an increase of population size in Mesola red deer, it is of utmost importance to eliminate the most detrimental factors to its recovery as soon as possible. Fallow deer should be removed by capture and culling, a greater forage availability should be created by means of supplementary feeding during the winter, improvement of forest habitat (increasing structural and specific heterogeneity, opening clearings), and improvement of pastures (reseeding, mowing, installing temporary exclosures). New semi-natural nuclei should be established, preferentially in similar Italian areas (forest tracts in lowlands, coastal woods, submediterranean and mediterranean environments). These new populations should be managed with great care from a genetic point of view, choosing the founders, and ensuring a gene flow by means of translocations to counter genetic drift. The creation of alternative stocks becomes indispensable if we consider the sanitary risks the present unique population is facing at the moment.

Acknowledgements: The authors wish to express their gratitude to S. Allavena of Ministero per le Politiche Agricole for having promoted this research, and to the following parties for assistance in the provision of samples and information on the origin of each animal: Ufficio Amministrazione Foreste 
Demaniali di Chieti; Ufficio Amministrazione Foreste Demaniali di Lucca; Comando Stazione Forestale Magliano dei Marsi Bis (AQ). Special thanks are due to the staff at Comande Stazione di Bosco Mesola (FE) for their kindness and valuable assistance in the field work. C. Caramalli, G. Nobili, G. Da Re are also acknowledged. G. B. Hartl is thanked for having provided samples of red deer from Central Europe for comparisons of electrophoretic phenotypes. S. Lovari provided valuable comments on the manuscript. The graphical support of S. Santarelli is greatly appreciated.

\section{References}

Baccus R., Ryman N., Smith M. H., Reuterwall C. and Cameron D. 1983. Genetic variability and differentiation of large grazing mammals. Journal of Mammalogy 64: 109-120.

Beninde J. 1940. Die Fremdbluteinkreuzung (sog. Blutauffrischung) beim deutschen Rotwild. Sonderheft der Zeitschrift für Jagdkunde: 1-112.

Castelli G. 1941. Il cervo europeo. Olimpia, Firenze: 1-393. [In Italian]

Caughley G. 1977. Analysis of vertebrate populations. Wiley \& Son, London: 1-234.

Dratch P. 1983. Enzyme variation in Scottish red deer, Cervus elaphus: population subdivision and its management implications. Proceedings of the $\mathrm{XV}^{\text {th }}$ Congress of the International Union of Game Biologists, Trujillo: 279-280.

Dratch P. and Gyllensten U. 1985. Genetic differentiation of red deer and North American elk (wapiti). [In: The biology of deer production. P. Fennessy and K. Drew, eds]. The Royal Society of New Zealand, Wellington, New Zealand. Bulletin 22: 37-40.

Dratch P. and Pemberton T. 1992. Application of biochemical genetics to deer management: what the gels tell. [In: The biology of deer. R. D. Brown, ed]. Springer-Verlag, Berlin: 367-383.

Farris J. 1972. Estimating phylogenetic trees from distance matrices. American Naturalist 106 $645-668$.

Feldhamer G. A., Stauffer J. R. and Chapman J. A. 1985. Body morphology and weight relationships of sika deer in Maryland. Zeitschrift für Säugetierkunde 50: 88-106.

Felsenstein J. 1989. PHYLIP. Phylogenetic inference package. Version 3.2. University of Washington, Seattle, Washington.

Fitch W. M. and Margoliash E. 1967. Construction of phylogenetic trees. Science 155: 279-284.

Fitzsimmons N. N., Buskirk S. W. and Smith M. H. 1995. Population history, genetic variability, and horn growth in bighorn sheep. Conservation Biology 9: 314-323

Frankel O. H. and Soulé M. E. 1981. Conservation and evolution. Cambridge University Press, Cambridge: $1-327$.

Franklin J. R. 1980. Evolutionary change in small populations. [In: Conservation biology. An evolutionary-ecological perspective. M. E. Soulé and B. A. Wilcox, eds]. Sinauer Associates Inc., Sunderland, Massachusetts: $135-149$.

Geist V. 1987. On the evolution of optical signals in deer. A preliminary analysis. [In: Bidlogy and management of Cervidae. C. M. Wemmer, ed]. Smithsonian Institution Press, Washington D. C.: $235-255$.

Geist V. 1989. Hybridization: extinction by default. [In: The big game of the world. W. Trense, ed]. Paul Parey, Hamburg: 381-383.

Gehle von Th. and Herzog S. 1994. Genetische Variation und Differenzierung von drei geographisch isolierten Rotwildpopulationen (Cervus elaphus L.) in Niedersachsen. Zeitschrift fir Jagdwissenschaft 40: 156-174.

Gilpin M. E. and Soulé M. E. 1986. Minimum viable populations: processes of species extinction. [In: Conservation biology: the science of scarcity and diversity. M. E. Soulé, ed]. Sinauer Assorciates Inc., Sunderland, Massachusetts: 19-34.

Groves C. P. and Grubb P. 1987. Relationships of living deer. [In: Biology and management of Cervidae. C. M. Wemmer, ed]. Smithsonian Institution Press, Washington D. C.: 21-59. 
Gyllensten U., Reuterwall C., Ryman N. and Sthl G. 1980. Geographical variation of transferrin allele frequencies in three deer species from Scandinavia. Hereditas 92: 237-241.

Gyllensten U., Ryman N., Reuterwall C. and Dratch P. 1983. Genetic differentiation in four European subspecies of red deer (Cervus elaphus L.). Heredity 51: 561-580.

Harris H. and Hopkinson D. A. 1976. Handbook of enzyme electrophoresis in human genetics. Amsterdam, North Holland.

Hartl G. B., Willing R., Lang G., Klein F. and Köller J. 1990. Genetic variability and differentiation in red deer (Cervus elaphus L.) of Central Europe. Genetics, Selection, Evolution 22: 289-306.

Hartl G. B., Lang G., Klein F. and Willing R. 1991. Relationships between allozymes, heterozygosity and morphological characters in red deer (Cervus elaphus), and the influence of selective hunting on allele frequency distributions. Heredity 66: 343-350.

Hartl G. B., Markov G., Rubin A., Findo S., Lang G. and Willing R. 1993. Allozyme diversity within and among populations of three ungulate species (Cervus elaphus, Capreolus capreolus, Sus scrofa) of Southeastern and Central Europe. Zeitschrift für Säugetierkunde 58: 352-361.

Hartl G. B., Klein F., Willing R., Apollonio M. and Lang G. 1995a. Allozymes and the genetics of antler development in red deer (Cervus elaphus). Journal of Zoology, London 237: 83-100.

Hartl G. B., Nadlinger K., Apollonio M., Markov G., Klein F., Lang G., Findo S. and Markowski J. 1995b. Extensive mitochondrial-DNA differentiation among European red deer (Cervus elaphus) populations: implications for conservation and management. Zeitschrift für Säugetierkunde 60: $41-52$.

Herzog S., Mushövel C., Hattemer H. H. and Herzog A. 1991. Transferrin polymorphism and genetic differentiation in Cervus elaphus L. (European red deer) populations. Heredity 67: 231-239.

Kaji K., Koizumi T. and Ohtaishi M. 1988. Effects of resources limitation on the physical and reproductive condition of sika deer on Nakanoshima Island, Hokkaido. Acta Theriologica 33: $187-208$.

Levene H. 1949. On a matching problem arising in genetics. Annales of Mathematical Statistics 20: 91-94.

Lorenzini R., Patalano M., Apollonio M. and Mazzarone V. 1993. Genetic variability of roe deer Capreolus capreolus in Italy: electrophoretic survey on populations of different origin. [In: Ecological genetics in mammals. G. B. Hartl and J. Markowski, eds]. Acta Theriologica 38, Suppl. 2: $141-151$.

Lowe V. P. W. and Gardiner A. S. 1974. A re-examination of the subspecies of red deer (Cervus elaphus) with particular reference to the stocks in Britain. Journal of Zoology, London 174: $185-201$.

Mattioli S. 1990. Red deer in the Italian peninsula, with particular reference to the Po Delta population. Deer 8: 95-98.

Mattioli S. 1993a. Low reproductive performance in a red deer population. Supplementi alle Ricerche di Biologia della Selvaggina 21: 535-539. [In Italian with English summary]

Mattioli S. 1993b. Antler conformation in red deer of the Mesola Wood, northern Italy. Acta Theriologica 38: 443-450.

McCullough D. R. 1982. Antler characteristics of George Reserve white-tailed deer. Journal of Wildlife Management 46: 821-826.

Murphy R. W., Sites J. W. B., Buth D. G. and Haufler C. H. 1990. Protein I: Isozyme electrophoresis. [In: Molecular Systematics. D. M. Hillis and C. Moritz, eds.]. Sinauer Associates Inc., Sunderland, Massachusetts: 45-126.

Mystkowska T. E. 1966. Morphological variability of the skull and body weight of the red deer. Acta Theriologica 11: 129-194.

Nei M. 1972. Genetic distance between populations. American Naturalist 106: 283-292.

Nei M. 1977. $F$-statistics and analysis of gene diversity in subdivided populations. Annales of Human Genetics 41: 225-233. 
Pemberton J. M., Albon S. D., Guinness F. E., Clutton-Brock T. H. and Berry R. J. 1988. Genetic variation and juvenile survival in red deer. Evolution 42: 921-934.

Perco F. 1984. [Research on cervids]. [In: Riserva Naturale Gran Bosco della Mesola: piano di gestione faunistica per il decennio 1980-1989. B. Minerbi, ed]. Ministero dell'Agricoltura e delle Foreste, Roma: 107-165. [In Italian]

Ryman N., Baccus R., Revterwall C. and Smith M. H. 1981. Effective population size, generation interval, and potential loss of genetic variability in game species under different hunting regimes. Oikos 36: 257-266.

Schreiber A., Klein F. and Lang G. 1994. Transferrin polymorphism of red deer in France: evidence for spatial genetic microstructure of an autochthonous herd. Genetics, Selection, Evolution 26: 187-203.

Scribner K. T., Wooten M. C., Smith M. H. and Johns P. E. 1985. Demographic and genetic characteristics of white-tailed deer populations subjected to still or dog hunting. [In: Game harvest management. S. L. Beason and S. F. Robertson, eds]. Caesar Kleberg Wildlife Research Institute, Kingsville, Texas: 197-212,

Slatkin M. 1985. Rare alleles as indicators of gene flow. Evolution 39: 53-65.

Soulé M. E. 1980. Threshold for survival. Maintaining fitness and evolutionary potential. [In: Conservation biology. An evolutionary-ecological perspective. M. E. Soulé and B. A. Wilcox, eds]. Sinauer Associates Inc., Sunderland, Massachusetts: 151-169.

Soulé M. E. and B. A. Wilcox (eds) 1980. Conservation biology. An evolutionary-ecological perspective. Sinauer Associates Inc., Sunderland, Massachusetts: 1-395.

Soulé M. E. 1987. Viable populations for conservation. Cambridge University Press, Cambridge: $1-320$.

Sneath P. H. A. and Sokal R. R. 1973. Numerical taxonomy. W. H. Freeman \& Co., San Francisco: $1-573$.

Sokal R. R. and Rohlf F. J. 1994. Biometry. 3 ed. W. H. Freeman \& Co, San Francisco: 1-896.

Strandgaard H. and Simonsen V. 1993. Genetic differentiation in populations of red deer, Cervus elaphus, in Denmark. Hereditas 119: 171-177.

Stratil A., Glasnák V., Pobák P, Cizová D., Gábršová E. and Kaláb P. 1990. Variation of some serum proteins in red deer, Cervus elaphus L. Animal Genetics 21: 285-293.

Ströhlein H., Herzog S., Hecht W. and Herzog A. 1993. Biochemical genetic description of German and Swiss populations of red deer, Cervus elaphus L. Animal Genetics 21: 285-293.

Ströhlein H., Herzog S. and Herzog A. 1994. Genetische Studien am Rotwild (Cervus elaphus L.) aus Hessen, Niedersachsen und Sachsen-Anhalt. Teil I: Populationsgenetische Parameter der Isoenzymgenetik. Zeitschrift für Jagdwissenschaft 40: 1-11.

Swofford D. L. and Selander R. K. 1989. BIOSYS-1. A computer program for the analsysis of allelic variation inpopulation genetics and biochemical systematics. Release 1.7. Illinois Natural History Survey, Champaign.

Whitehead K. 1964. The red deer of Great Britain and Ireland. Routledge and Kegan Paul, London: $1-597$.

Workman P. L. and Niswander J. D. 1970. Population studies on southwestern Indian tribes, II. Local genetic differentiation in the Papago. American Journal of Human Genetics 22: 24-49.

Wright S. 1969. Evolution and the genetics of populations. Vol. 2. The theory of gene frequencies. University of Chicago Press, Chicago, Illinois: 1-580.

Received 23 March 1998, accepted 30 April 1998. 